\title{
Corporate Social Responsibility in Food and Beverage Industry: An Analysis Study of Soft Drinks Sector in Algeria
}

\author{
Ounane Boumediene \\ Associate professor, Faculty of economics, \\ University of Sidi Bel Abbes. Algeria, \\ Yahiaoui Nour El Houda
}

$\mathrm{PhD}$ student, Faculty of economics, University of Sidi Bel Abbes, Algeria

Doi: 10.19044/esj.2018.v14n1p190 URL:http://dx.doi.org/10.19044/esj.2018.v14n1p190

\begin{abstract}
The aim of this study is to highlight the most important issues of social responsibility for companies in the Algerian beverage sector. In Algeria, despite growing concerns of consumers and health advocates in effects associated with high levels of consumption of beverages on public health, along with other issues such as; the quality of drinks, percentage of sugar, ingredients, packaging. Studies dealing with social responsibility in this sector are rather scarce.

Our results show that applying CSR principles stills not very common in this field and too much efforts are needed in order to legitimize the activity of the enterprises, likewise an increasing acceptance of social responsibility principles so that to establish the rules of ethical practices in the future. Finally, some urgent measures, such as installing a good information system as well as a set of laws and standards that regulates CSR, and reducing the effect of the informal sector should be undertaken by the Algerian government.
\end{abstract}

Keywords: Corporate social responsibility, food and beverage industry, soft drinks sector, health concerns, Algeria

\section{Introduction}

While corporate social responsibility (CSR) is increasingly acknowledged as an important business issue, there is still relatively little practical guidance available to help companies respond to the challenges it presents. Tools that do exist tend to be applied to any company and can therefore be somewhat generic; there is very little guidance that addresses the specific CSR challenges faced by companies in specific industry sectors. (Prescott et al 2002). 
Though, CSR is of high relevance for food and beverage industry as it provides human basic needs and has a strong impact on public health. And CSR initiatives have become a core part of business activities in the food and beverage industry, in particular for companies with high-value consumer brands. Plus, the food safety and quality issues has long received considerable attention in the agricultural economic research, researches on CSR with a focus on the food sector is still scarce.

For the year 2012, according to $\mathrm{APAB}^{6}$, the Algerian soft drinks production was more than 3.7 billion liters across all sub-sectors with a turnover of almost 215 billion dinars. In terms of consumption, it has been estimated at more than 54 liters per capita per year; making this sector among the most dynamic of the food industry in Algeria with a contribution of $7 \%$ of food production and a significant part of $25 \%$ distributed revenue in all industry (with 17,000 direct jobs and 30,000 indirect jobs) (PME2,APAB 2012).For the year 2014, Algeria is considered as Africa's fourth largest soft drinks market. (ACE 2014).

These high conception levels associated with the growing health and wellness concerns put forward the question of CSR in this sector, especially if taking in consideration the huge weight of informal sector and the fact that so far the regulations gap has not protected consumers from misleading claims in this sector.

The main objectives of this paper are three-fold: (1) to link the rich body of literature on CSR to the food and beverage industry; (2) to develop a conceptual framework that can be used in identifying what CSR means for companies in soft drinks sector; and (3) apply this conceptual framework to present a case study of the major CSR concerns that respond to soft drinks sector specific challenges in Algeria rather than generic CSR solutions.

The paper starts with a definition of the concept of CSR in Section (1). In section (2), we discuss the specific issues of CSR in the food and beverage industry, followed by an analysis of CSR concerns related specifically to the soft drinks sector. Section (3) is a case study of CSR in the soft drinks sector in Algeria.

\section{Literature review}

- $\quad$ Defining Corporate Social responsibility (CSR)

${ }^{6}$. The Association of Algerian Beverage Producers (APAB) is an association of beverage producers that dominates $85 \%$ of the Algerian beverage market, in 2013 this association has accomplished considerable achievements such as training on the use of food additives, creating the Consortium export of beverages, promoting human resources where the establishment of a map of the beverage industry and trade levels compensation related to it, creation of the collective mark «Buvez Tranquille», supporting the accreditation of laboratories, development of a drink cluster in the region of Soumam, in Bédjaïa' department. 
CSR has experienced a long history. Its meaning has been discussed in various ways and ongoing debate on the consistent CSR domains. Although, many researchers and business persons have been engaged in, it is known that there is neither a general consensus nor a universal agreed on the definition of CSR nor a range of its main aspects.

The meaning and practice of the CSR has been changed and altered since the 1950s, when the classical view of CSR was limited to philanthropy, besides the contribution that a business provided for resolving social problems. CSR defined initially by Bowen (Responsibilities of the Businessman, 1953), "The term doctrine of social responsibility refers to the idea, now widely expressed that taking into account a voluntary social responsibility of the businessman is, or could be an operational mean to solve economic problems and reach more broadly economic objectives that we pursue". (Aquier, grand 2007)

Recently, this view has been developed to include meeting legal requirements and broader expectations of stakeholders in order to contribute to a better society through actions in the workplace, market place, local community and through public policy advocacy and partnerships.

For The World Bank, CSR includes: "The commitment of business to contribute to sustainable economic development, working with employees, their families, the local community, and society at large to improve their quality of life, in ways that are both good for business and good for development"

As to The European Commission (2001): "it is essentially a concept whereby companies decide voluntarily to contribute to the society to make it better and environmentally cleaner".

For the World Business Council for Sustainable Development (2000), defines CSR as "the continuing commitment by business to behave ethically and contribute to economic development while improving the quality of life of the workforce and their families as well as of the local community and society at large".

According to ISO 26000 (ISO 2010), a newly introduced guideline on social responsibility of organizations -which is the result of a 5years discussions of multiple stakeholder's groups from 99 countries-, CSR is defined as the responsibility of an organization for the impacts of its decisions and activities on society and the environment, through transparent and ethical behavior that contributes to sustainable development, including health and welfare of society, takes into account expectations of stakeholders, is in compliance with applicable law and consistent with international norms of behavior and is integrated throughout and practiced in an organization's relationships. 
Early notions of CSR on an academic level can be traced back to the 1960s. In 1991 Carroll presented CSR as a multi-layered concept in a pyramid that analyses the dimensions of CSR as interrelated aspect. It starts with economic responsibilities; companies are created to provide goods and services to the public and to make profit. This is the foundation upon which the other three responsibilities rest. The second layer consists of the legal responsibilities of a company. The ethical responsibilities are practices that have not been codified into the law. Societal members expect a company to do what is right and fair. Lastly, at the top of the pyramid companies have a philanthropic responsibility. Business organizations are expected to be good corporate citizens and to improve the quality of life of a given society. (Caroll.a.b 1991)

Figure 01: Carroll's dimension of CSR pyramid

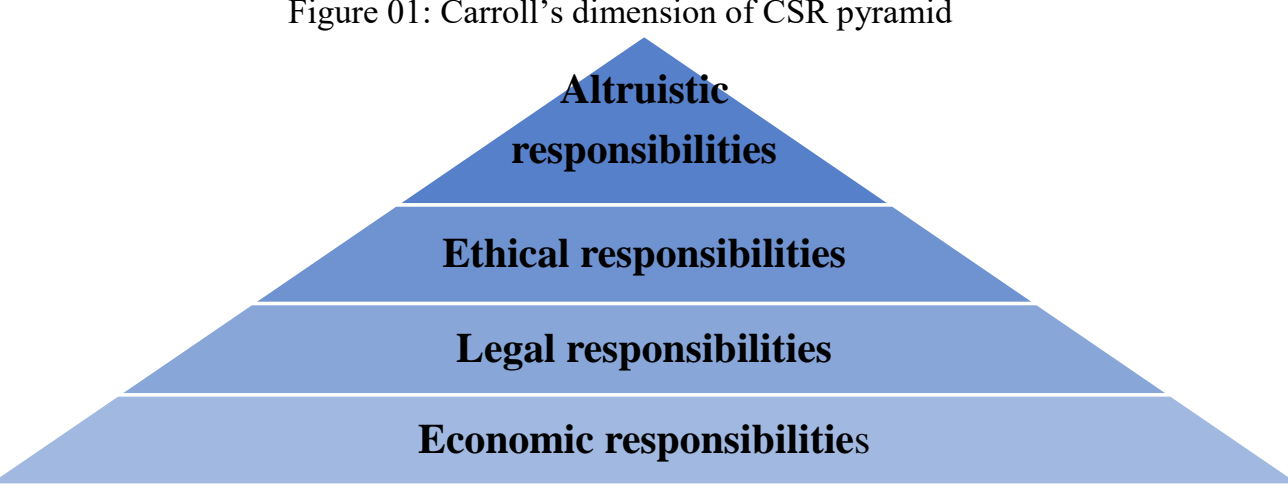

Source: Carroll Archie B, the pyramid of corporate social responsibility: toward the moral management of organizational stakeholders, business horizons, university of Georgia, JulyAugust 1991, P 7.

\section{Corporate social responsibility in food and beverage industry}

All sectors of the economy are affected by the increasing demand to respect CSR. However, The CSR issues may appear fundamental in a sector while having less importance in the other; given its characteristics the pressure exerted on companies likely differs. For example: there are typically industries that are challenged on their practices for sustainable development, such as mining and extractive industries that have a stronger impact on the environment. (Hartman 2011)

Beyond certain activities perceived as controversial as tobacco, gambling, weapons, spirits, nuclear ... all business sectors remains concerned by practices such as not deemed responsible child labor, testing on animals, the use of pesticides, emissions of greenhouse gases ... It is around these issues that are built the questions and expectations of the different stakeholders. Once these issues are identified by sector, this will allow companies to manage their CSR practices. 
In 2012, a study put forward by Ipsos Global Reputation Center ${ }^{7}$ (Ipsos 2012), where he looks at various factors impacting company's reputation in the Food and Beverage sector and the Key findings were:

- Globally, the food and beverage sector is not highly trusted. Food and beverage companies generate particularly low levels of trust especially in Europe, Canada and Australia.

- $\quad$ Food and beverage companies face a fairly high risk of consumer regulation;

- Jobs and product safety are the top corporate social responsibility (CSR) priorities for the food and beverage industry;

- When given the opportunity to express a second most important area, reducing the environmental impact of manufacturing becomes one of the top choices.

- Familiarity is half the battle - to be known is to be liked, to be liked is to be trusted.

Figure 02: global CSR priorities for the food and beverage industry

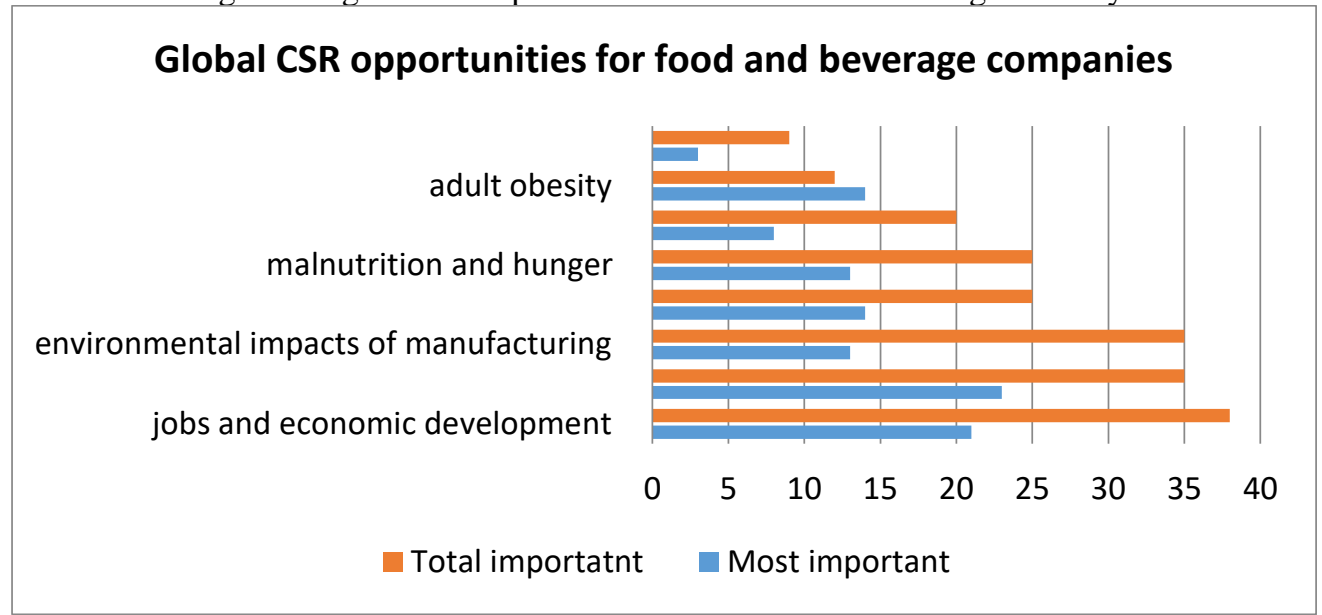

7 . Four times a year, the Ipsos Global Reputation Center conducts research on the issues impacting various business sectors and the reputations of companies in those sectors, it helps its clients to identify the issues and actions that build corporate reputation and deliver corporate brand equity.www.ipsos.com 


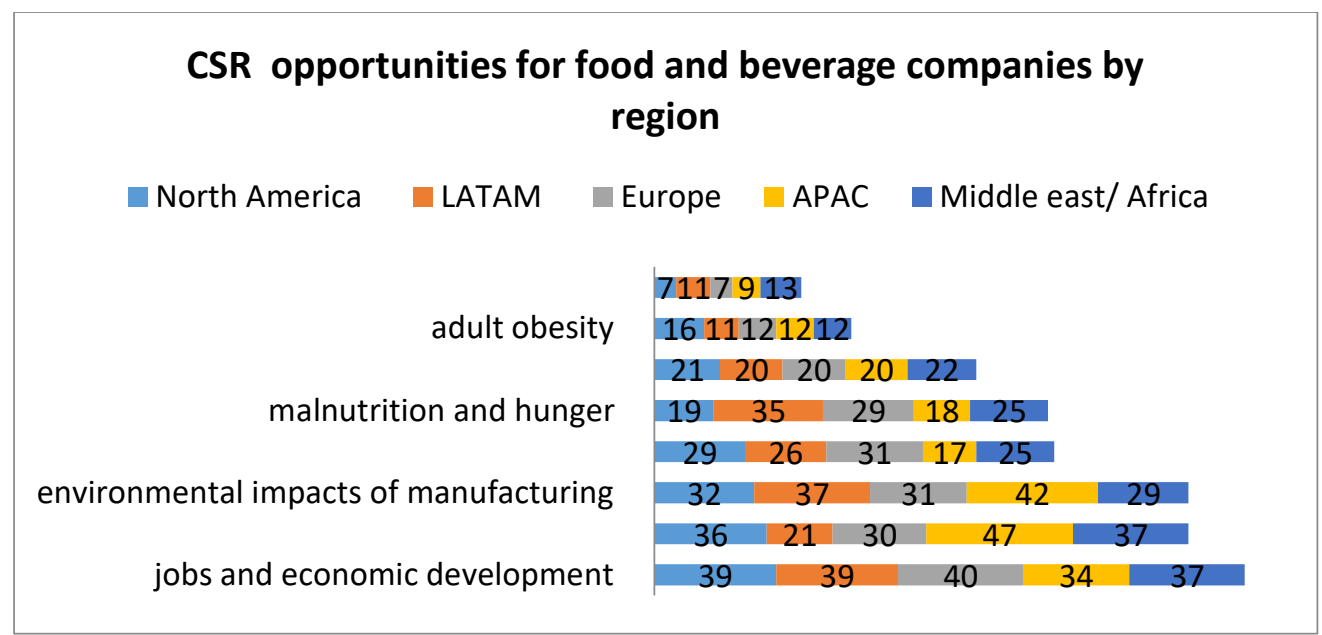

Source: Ipsos, Reputation Snapshot for the Food and Beverage Sector, Ipsos Global Reputation Centre, 2012, p 04

There are myriad of features that make the Algerian food and beverage industry an exemplary case for CSR. One distinguishing feature is enormity of size, the Food and beverage Industry is the second largest industry in Algeria. The year 2010, this industry represents $52 \%$ of production, $41 \%$ of the added value, $57 \%$ of the net surplus and $58 \%$ of intermediate consumption of the all industrial sector.

The weight of this industry is due to the size of the domestic market, driven by significant demographic and budgetary coefficient of households. Indeed, it has more than $40 \%$ of private household expenditure. This weight is even more significant when added the distribution of food products, restoration and catering (PME2,APAB 2012).

Figure 03: Algerian industrial sector production structure

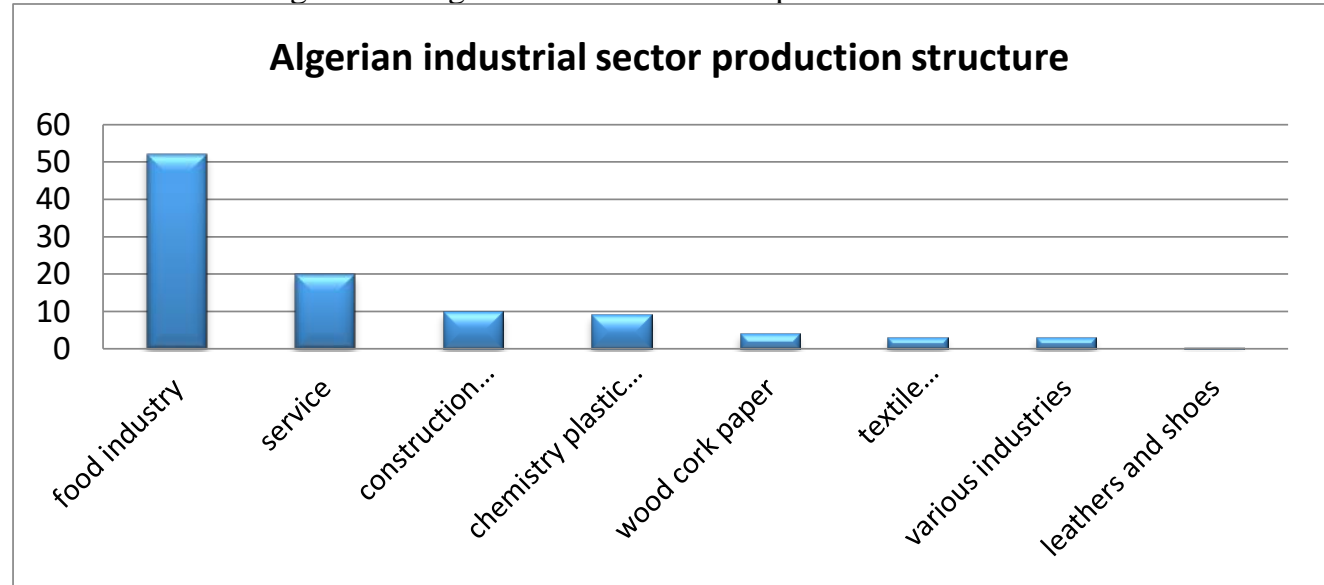

Source: national statistics office, ONS, http://www.ons.dz/ 
That's without forgetting its contribution to income distribution, in 2010; the food and beverage industry sector distributed 33,656 MDA as employees' remuneration of total industry 136,876 MDA. A significant contribution of $25 \%$ make It occupies the second position of industry sector.

Figure 04: food and beverage industry contribution in employees 'income

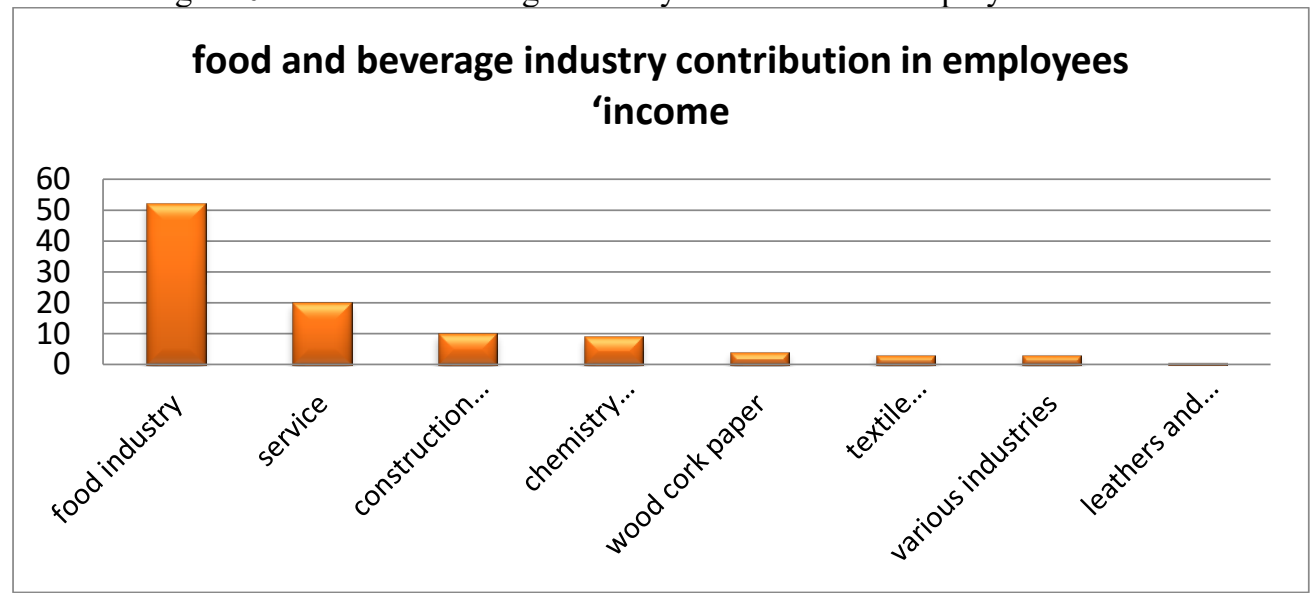

Source: national statistics office, ONS, http://www.ons.dz/

In addition to its large size, we should take in consideration its growth potential, the food and beverage industry enjoys the benefit of unwavering demand simply because everyone must eat, taking in regard the influence of globalization and worldwide spread of western urbanized lifestyle; ensure that this industry will continue to grow in coming years.

The most important distinguishing feature is that food and beverage business has been described as 'a minefield of cultural and economic sensitivities. Food is different from most other product because we ingest it, as food covers basic human needs people have very strongly-held views about what they eat and drink.

This creates a uniquely complex set of responsibilities and requirements for companies in this industry; and brings forward ethical issues that go beyond economics such as human health, production of the raw materials (animal welfare), disease risk, quality, healthiness and safety of products (nowadays, Some components of food such as fat, sugar and salt have been directly linked to negative physical effects on human body), product marketing and the change of eating habits among consumers and quality of life.

Finally, in the context of CSR the food sector faces a number of significant environmental challenges (e.g. energy and water use and waste) as well as social challenges (labor conditions) especially with the rapid evolving of consumer's awareness and concerns about environmental and social issues. 
- $\quad$ Soft drink industry corporate social responsibility concerns:

In 2007 Coca-Cola ${ }^{8}$ launched its sustainability framework Live Positively embedded in the system at all level, from production and packaging to distribution. The company's CSR policy Live positively establishes even core areas where the company sets itself measurable goals to improve the business' sustainability practices. The core areas are beverage benefits, active healthy living, the community, energy and climate, sustainable packaging, water stewardship and the workplace. (Cristina et al 2012)

Generally, CSR motivating Concerns in the soft drink industries are evident in The Coca Cola Company's 2009 Annual Report. (Coca-Cola 2009) a. Health focus and concerns

Consumers, public health officials and government officials are becoming increasingly concerned about the public health consequences associated with obesity, particularly among young people. Health advocates are encouraging consumers to reduce consumption of sugar-sweetened beverages, or other nutritive sweeteners.

b. Sustainability focus and concerns

The soft drinks industry also faces pressure from an environmental angle. Key objective for businesses is to improve their use of resources including reducing energy consumption, increasing overall production efficiency, reducing water waste and carbon costs. Factories continued to highlight the importance of recycling via the Recycle Now logo across all its packaging.

I.Case study: CSR in the Algerian soft drinks sector:

- $\quad$ Algerian soft drinks sector:

The sector of soft drinks is among the most dynamic sectors of the food industry in Algeria, it contributes with $7 \%$ of food production. Because of the very important economic growth rate it has made, the progress it has registered on the diversification and the quality of products. It is also distinguished by the presence of major companies and the organization of the profession.(PME2,APAB 2012)

\footnotetext{
${ }^{8}$. Coca-Cola started its business in 1886 as a local soda producer in Atlanta, Georgia (US) selling about nine beverages per day. By the 1920s, the company had begun expanding internationally, selling its products first in the Caribbean and Canadian markets and then moving in consecutive decades to Asia, Europe, South America and the Soviet Union. By the end of the 20th century, the company was selling its products in almost every country in the world. In 2005 it became the largest manufacturer, distributor and marketer of non-alcoholic beverages and syrups in the world. Coca-Cola is a publicly-held company listed on the New York Stock Exchange (NYSE).
} 
Figure 05: Algerian soft drinks sector production

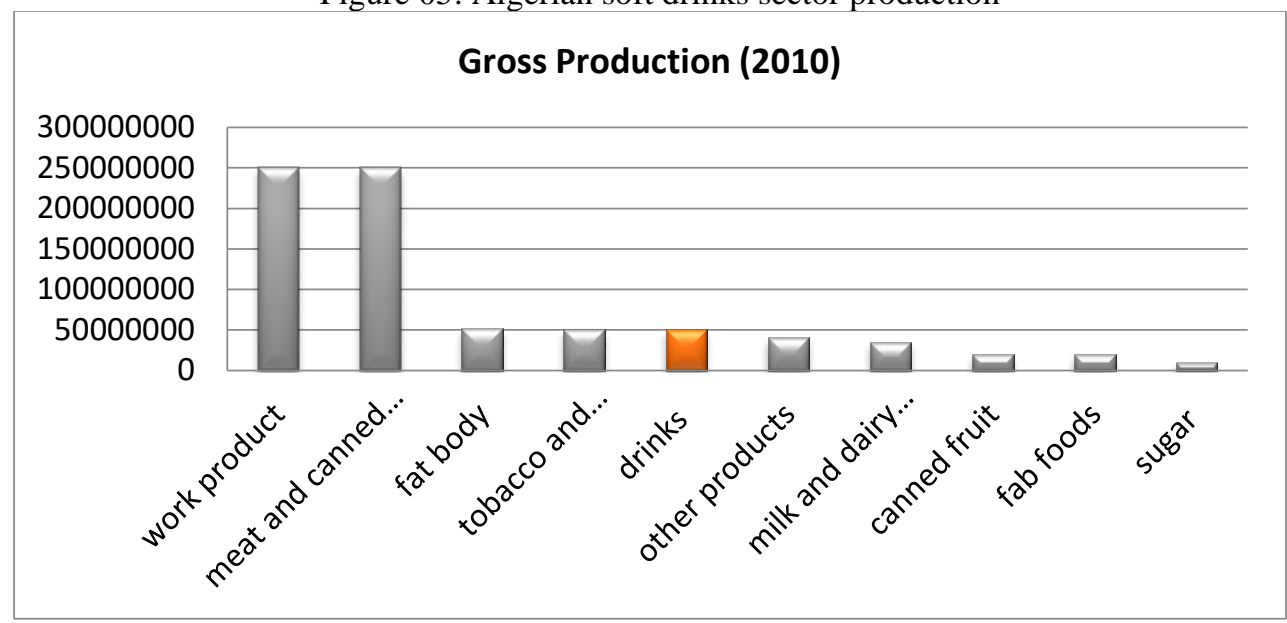

Source: national statistics office, ONS, http://www.ons.dz/

Algeria is considered as Africa's fourth largest soft drinks market, according to the APAB, in 2012, the beverage production was more than 3.7 billion liters across all sub-sectors with a turnover of almost 215 billion dinars. During the same year, the sector had 17,000 direct jobs and 30,000 indirect jobs. In terms of consumption, it has been estimated at more than 54 liters per capita per year.

According to $\operatorname{UKTI}^{9}$ (2012), 27\% of the Algerian population is below the age of 14 , creating a large market for sugar and confectionery products such as biscuits, crisps, chocolates and soft drinks. (ACE 2014)

According to Euro monitor (2013), the Algerian soft drinks sector is recording positive levels of growth due to a combination of several factors such as rising disposable income levels, giving a higher purchasing power, the development of the country's consumer foodservice industry and the flourishing of hypermarkets and supermarkets helping a rise of modern grocery retailers outlets, New product launches, advertising and promotional campaigns, not to mention the ongoing changes because of Globalization and worldwide spread of western urbanized lifestyle, leading to rising numbers of consumers eating out.

On the period 2005-2010, the annual average progress of this sector was: $14 \%$ for production rates, $15 \%$ for intermediate goods consumption and $13 \%$ for added value.

9 . UK TRADE \& INVESTMENT is a non-ministerial department that works with UK based businesses to ensure their success in international markets through exports. It encourages and support overseas companies to look at the UK as the best place to set up or expand their business. 
Here two points are worth noting: first, even if we include price indices for the period, the increase remain high, meaning a product improvement volume. The level of growth in the beverage industry (14\% per year) was twice that's of the all food industry ( $7.1 \%)$. Second, the value added rate deteriorated from $42 \%$ in 2005 to $39 \%$ in 2010 ; because the sector is facing input prices increase (mainly imported) that affect sale prices.

Figure 06: Algerian soft drinks sector growth levels

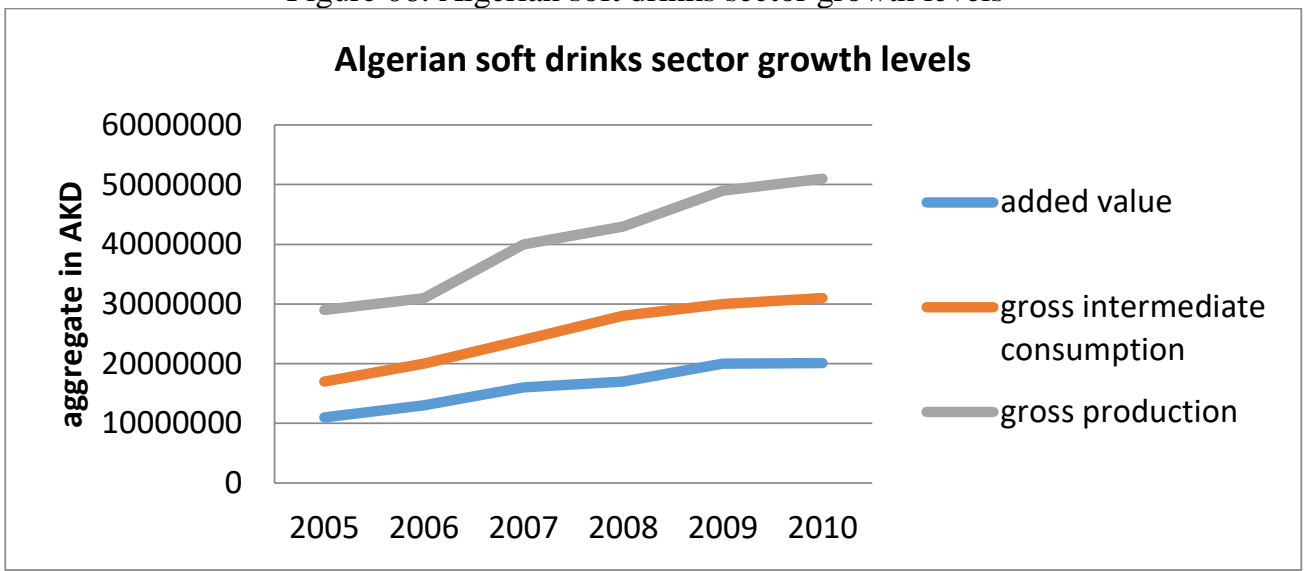

Source: national statistics office, ONS, http://www.ons.dz/

The distribution of the added value is another strength feature of this sector. The labor and capital get the most significant share, followed by the shareholders' dividends.

Figure 07: Algerian soft drinks added value distribution

$$
\begin{aligned}
& \text { Algerian soft drinks added value distribution } \\
& \begin{array}{ll}
\square \text { amortization } & \text { taxes related to production } \\
\square \text { employees wages } & \text { net operating surplus }
\end{array}
\end{aligned}
$$

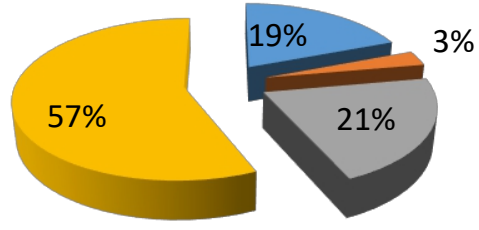

Source: national statistics office, ONS, http://www.ons.dz/

Based on the Directory agribusinesses MIPMIPI 2009, it is estimated that employment in the soft drinks industry (excluding National Office of Wine Marketing) is nearly 14,800 direct jobs and about 37,000 indirect jobs. 
The beverage sector is divided into two main segments: soft drinks (nonalcoholic) and Alcoholic Beverages. Considering the respective share of these two segments, we can see that the soft drinks dominate $91 \%$ of the beverage sector production and $93 \%$ of added value.

Nowadays, the private sector dominates more than $80 \%$ of gross production and $86 \%$ of added value; this considerable progress results from the strong dynamic investment started from the 1990s and the privatization of public companies.

Figure 08: Algerian soft drinks legal and segmental structure

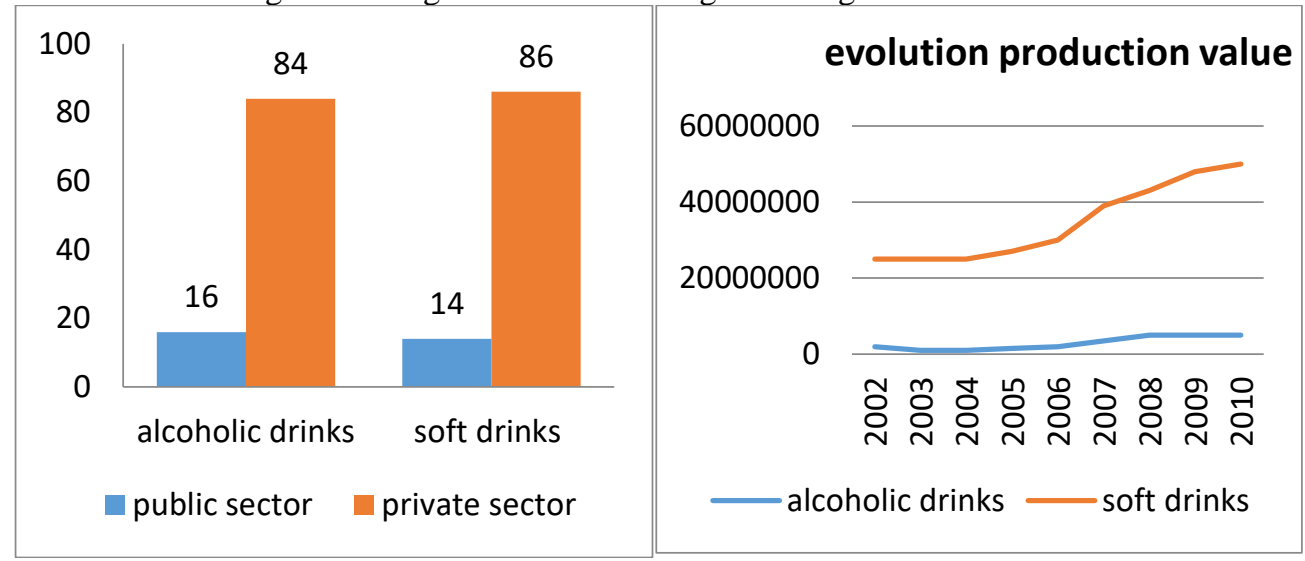

Source: national statistics office, ONS, http://www.ons.dz/

- $\quad$ Algerian soft drinks sector products:

In this study, we try to remain precise and consistent with our terminology. That's why we must make the following terms clear in meaning:

Soft drink: is defined as any type of nonalcoholic beverage produced by a soft drink manufacturer; it includes:

Bottled water: is drinking water (e.g., source water, distilled water, mineral water,..) packaged in plastic or glass water bottles. It may be carbonated or not.

Sugar-sweetened beverage: term used by public health advocates to describe a soft drink containing caloric sweetener (e.g., sugar, high-fructose corn syrup)

Carbonated soft drink: type of soft drink that is carbonated; includes both nondiet and diet soft drinks

Fruit beverage: type of soft drink that either contains fruit juice or is fruit-flavored Juice drink: soft drink that contains juice and other ingredients

Fruit-flavored drink: soft drink that is flavored to taste like fruit but does not contain juice

Bottled: refers to beverages that are packaged in bottles or cans

Non diet: refers to beverages that contain calories, usually from an added sweetener 
Diet: refers to beverages with zero calories and usually sweetened with no caloric sweeteners

- $\quad$ CSR issues in the Algerian beverage sector:

a. Emerging health and wellness concerns

Although the high levels of conception, Health remained high on the consumer agenda, the growing health and wellness concerns, those Health and wellness concerns have resulted against artificial sweeteners, which is having a particularly strong influence on sales of carbonates in Algeria. One of the outcomes of this has been slower growth rates in carbonates, to the benefit of flavoured bottled water, juice and nectars, all of which are perceived as healthier alternatives.

Even low-income consumers are happy to purchase juice, especially nectars, despite the relatively high unit price as they are considered ideal replacements for more expensive fresh fruit.

So far the regulation gap has not protected consumers from misleading health and wellness claims that nectars are often purchased because they are perceived as being healthier even though they contain a very limited amount of real fruit. The authorities recently took steps to standardise food and drinks products, resulting in a new labelling system, effective from November 2014. b. Fast Tends to Sports and energy drinks

Sports and energy drinks continues to generate high value and volume growth rates in Algeria, in 2013 it registered 10\% total volume growth and $18 \%$ total value growth. (www.fastmr.com 2013). Domestic manufacturers are now making attempts to seize the potential of the category, which has so far been dominated by imported brands such as Red Bull, by launching numerous new products such as Burn (Fruital Coca-Cola Spa) and Xploza (PromasidorDjazair) manufactured under license in Algeria.

Nevertheless, the boundaries between sports drinks and energy drinks remain quite blurred. All products in the category target mainly the young male audience, teenagers and young adults, who continued to perceive energy drinks as a fashionable beverage.

In order to attract new consumers, local brands rely mainly on pricing strategies to offer products which are much cheaper than imported brands. In order to distinguish themselves from imported brands and win the loyalty and recognition of consumers, the marketing campaigns of domestic brands focus on national pride, emphasising local production and relying on the endorsement of popular local celebrities. (Euromonitor 2014)

c. The level of sugar in soft drinks

Many consumers estimate that the level of sugar in Drinks is very important, and took aware of the negative effects of sugar, including promoting the development of diabetes and other diseases. In other hand, the producers have an interest in low level of sugar, because financially, sugar 
coasting is more expensive than anything else. But the Algerian consumers like sweet products, so it is the consumer who decides. (Benarab 2014)

The Ministry of Commerce and the Association of Algerian Producers of Beverages (APAB) have initiated a thinking of setting to decrease sugar levels in drinks. The aim of this process is to protect public health and to decrease Sugar expensive bill to Algeria.

d. ASPARTAME a dangerous substitute of sugar:

Coca-Cola Light, Coca-Cola Zero (without sugar) or Pepsi light, are the main drinks in which the classic sugar is not within the composition. Those Both multinationals use instead of sugar aspartame, Code name E951 in the European codex, which is according to the scientists who conducted several researches, dangerous harmful for consumer's health. Manufacturers and other enthusiasts for aspartame believe that the respect for the daily dose, estimated at $40 \mathrm{mg} / \mathrm{kilo}$ body, has no effect on the health. Also diabetics believe that light drinking decrease glucose in the blood and reduce weight. This thesis is contradicted by scientists. (Ababsa 2014)

researchers concluded that the E951 (also commonly called false sugar), is responsible for tumors, confirming to a US study carried in 1996, even respecting the acceptable daily intake, but as headache, nausea, blurred the view and risk of worsening diabetes and obesity.

This is why most of our diabetics suffer also from cataract which requires surgical intervention. When we know that Algeria has 1.5 million diabetics receiving all supports and benefiting the free care (Not less than 10,000 DA per month on medications only), we can imagine the invoice that CNAS pays. It is not for nothing that the Venezuela has prohibited Coca-Cola Zero marketing in 2010.It should be mentioned that light drinks are the delight of producers because it generates a capital gain regarding aspartame low prices.

e. Product's Packaging

Internationally, the dominant packaging trends are: Boxes (cans): 50\%, Cardboard (bricks): 13\%, Plastic (PET): 30\%, Glass: 7\%. The Algerian market presents a range of packaging similar to that of the global industry. National Beverage packaging has diversified in accordance with international standards and the global trends in packaging.

Figure 09: Algerian soft drinks Product's Packaging

\begin{tabular}{|c|c|c|c|c|}
\hline Products & Plastic & cardboard & can & glass \\
\hline Water & $99.9 \%$ & & & \\
\hline soft drink & $60 \%$ & & $5 \%$ & $35 \%$ \\
\hline $\begin{array}{l}\text { Conditioned } \\
\text { bottled juice }\end{array}$ & $60 \%$ & $15 \%$ & & $25 \%$ \\
\hline beer & & & $70 \%$ & $30 \%$ \\
\hline wine & not determined & not determined & not determined & dominant \\
\hline
\end{tabular}


The recycling of beverage packaging, remains an embryonic activity in Algeria, is also addressed in this guide, insisting the need to develop this activity, but by using specific techniques because those products affect directly the health of consumers.

f. Misleading labeling

In the soft drinks industry Labeling is a huge problem, considered as misleading to consumers and one of the brakes of CSR in this industry, especially for the juices where it is not normal that the packaging indicates that a juice is made of natural fruits while it is produced from flavors.

g. The weight of informal sector:

According to the Algerian Federation of consumers (AFC), $10 \%$ of soft drink and fruit juice producers ${ }^{10}$ belong to informal sector and have no trade register.For the AFC President, these producers are considered as a permanent danger to consumers because of the use of carcinogens in drinks composition, without going through the quality control laboratories .

The Association of Algerian Beverage Producers (APAB) urges the authorities to strengthen the drinks quality control, the association sounded the alarm about the proliferation of beverage brands in the domestic market, not only drinks produced here in Algeria but also some imported counterfeit drinks.

The association notes that the informall producers fail to comply with hygiene rules, use prohibited ingredients and misuse certain components (sweeteners, conservatives...) without forgetting the use of dangerous production processes such as uncontrolled packaging. These large quantities of drinks unfit for consumption, are distributed daily in informal markets, where for exemple the two-liter juice bottle price doen't exceed 50 dinars. (Nahli s.d.).

- $\quad$ CSR initiatives in the soft drinks sector

In order to promote this sector and put it on the path of innovation and sustainable development, it is evident that CSR foundations, practices and concerns have become a core part of this sector activity. In this light, many initiatives have been taken mostly by the Association of Algerian Beverage Producers (APAB); its goal is to contribute to the harmonization, normalization and standardization of soft drinks sector good and ethical practices.

a. A code of good Conduct in the beverage sector

the Association of Algerian Beverage Producers (APAB) has developed a Code of Business Conduct by adopting rules of ethics, as a repertoire of principles of good conduct and best practices for leaders of soft

${ }^{10}$. Recalling that the beverage industry currently has some 700 producers nationwide. 
drinks companies and staff each at its respective level, in order to maintain order in the sector. (GIZ et APAB 2014)

b. Facing Misleading labeling problem

It is to face misleading labeling problems that the (APAB) has recently launched the collective mark "Drink quiet" that will allow consumers to ensure the quality of the soft drink with the labeling on beverage packaging.

c. A technical guide on the use of packaging

The Association of Algerian Beverage Producers (APAB) published a technical guide on the use of packaging in the beverage industry. This guide, developed in collaboration with the IDEA program - Innovation, sustainable development, entrepreneurship, employment-(GIZ), aims to provide professionals with recommendations for appropriate use of different types of packaging possible.

The guide discusses in detail the different packages, it takes into account the changing legal requirements (national and European), as well as technological and environmental developments in packaging in the food industry, the choice of a drink packaging results of matching materials, packaging technologies and properties of a drink to be preserved. It is for this reason that the guide set out to study the properties of beverages and preserve the properties of different usable packaging materials. ${ }^{11}$

d. A guide for good hygiene practices

The guide applies to fruit juices, nectars and juice drinks, which make or not the subject of a microbiological stabilization treatment. The guide is applicable to products packaged for the final consumer (either in a package from $5 \mathrm{ml}$ to 10 liters), with the exception of preparations for industry or catering. The guide is intended for professionals and covers the activities area from raw materials reception and storage the packaged product destined to the final consumer. (APAB PME2 2011).

${ }^{11}$. It should be noted that the first quality of a food packaging is undoubtedly to ensure the protection of the food against the risk of chemical and microbiological contamination, so it uses so-called barrier materials. In short: the packaging structure is always selected so that the container retains intact the properties of the product. 
e. $\quad$ A Guide to adjust the use of food Additives ${ }^{\mathbf{1 2}}$ in soft drinks

APAB edited a user guide of food additives in the soft drinks, to be a comprehensive reference to the sector actors witch complies with Executive Decree No. 12-214 of 15 May 2012 laying down conditions and terms of use of food additives in food intended for human consumption.(PME2 2014)

This guide includes indications about: The objectives and uses of Food Additives, food Additives in soft drinks. This guide will be reviewed by the regulatory watch cell of APAB keep up with the legislative and regulatory developments.

f. Responding to enviromental and social concerns

In terms of environmental standards, APAB has also made considerable progress, by helping several producers obtaining ISO14001 certification. From a social perspective, encouraging producers to set up Hygiene, Security and Environment department committed to respecting hygiene and food security standards as well as workplace ergonomics, where for some of them been culminated with the ISO22000 certificate for food safety.

II.Summary and conclusions

In the Algerian soft drinks sector, CSR is still in its initial steps, CSR efforts aim essentially to legitimize corporation's activities and increase corporate acceptance in order to set in future for a foundation of good and ethical practices. We can conclude that the most important obstacles facing CSR initiatives in Algerian soft drinks sector are:

a. An information system regarded as insufficient

Can be summed up in the lack of a comprehensive and reliable information system on the activities of the Algerian soft drinks sector, the lack of producer's transparency, the absence of an adequate professional context involving all soft drinks producers until the establishment of the Algerian Beverage Producers Association (APAB); despite that, the (APAB) remains limited (especially for small operators and companies).

b. Inadequate and poorly applied regulation and standards

Regarding Algerian regulation, we can note that the weakness or even the absence of regulation concerning certain segments of activity or product

12. Additives are commonly used in the food industry. Despite their sophistication relatively recent technology, food additives have been used for centuries: Yeast (baking powder), salt, saltpeter, thickeners, dyes, are known and used for a long time. Over the past 50 years, developments in food science and technology have resulted in the discovery of new substances that may fill many functions in various food products. These food additives include: emulsifiers, sweeteners and a broader range preservatives used to slow product rancidity while maintaining the taste, etc. Additives therefore play a key role in maintaining the quality and the characteristics of food, in particular to take into account conditions such as environmental temperature changes, oxidation and bacterial exposure, which can change their original composition. 
types (e.g. Juice) especially in the domain of hygiene standards, the manufacturing process and the storage of goods involve many dangers to the health of consumers.

Also, Soft drinks classification procedure is deemed unclear, because of the lack of national standards and professional references covering manufacturing drinks (especially flat fruit drinks, carbonated and fruity water), causing a huge failure of a large number of Algerian companies in respecting the minimum standards of food hygiene and safety.

c. A sector characterized by a large informal market

The main obstacle in the way of a socially responsible sector is the huge size of the informal market, the rise of counterfeiting as a significant number of truly non-qualified manufacturers use known brands bottles and dubious drinks, resort to the use of flavorings, colorants and other additives considered as illegal in many cases, the excessive use of thickeners and sugar substitutes. The unfair practices of Sales such as selling at too low prices, local sales without invoices and Anarchic, fraudulent, smuggling imports practices.

\section{References:}

1. Ababsa, Faouzia. «Boissons light: Le bonheur des uns fait le malheur des autres.» L'éco, Bimensuel de l'économie et de la finance, $\mathrm{n}^{\circ} \mathrm{n}^{\circ} 92$ (du 1er au 15 juillet 2014): 11-12.

2. Arab African Conferences Exhibtion. food and beverage industry in EGYPT and MENA region. ACE, 2014.

3. APAB, PME2. "Guide des bonnes pratiques d'hygiène.» industrie Algérienne de jus de fruits, nectars et produits dérives. decembre 2011.

4. AQUIER.A, GRAND.J.P. «aux sources de la responsabilité sociale de l'entreprise: RElecture et analyse d'un ouvrage fondateur:socialresponsabilities of the businessman d'HOWARD BOWEN (1953).» finance controle stratégie 10, $\mathrm{n}^{\circ} 2$ (2007): 5-35.

5. Benarab, Nassima. «Les Algériens déboursent en boissons 5,5\% du total des dépenses alimentaires. 66 litres par personne et par an.»L'éco:Bimensuel de l'économie et de la finance, $\mathrm{n}^{\circ} 92$ ( du 1er au 15 juillet 2014 2014): 8-9.

6. CAROLL.A.B. «the pyramide of corporate social responcibility: toward the moral management of organizational stakeholders.» business horison 04 (1991): 39-48.

7. Coca-Cola. «The Coca-Cola Company, '2010 Annual Review'.» http://www.thecocacolacompany.com/ourcompany/ar/pdf/TCCC_2010_Annual_Review. 2009. (accès le 12 21, 2015).

8. CRISTINAA. Cedillo Torres, Mercedes Garcia-French, Rosemarie Hordijk, Kim Nguyen, Lana Olup. «Four Case Studies on Corporate 
Social Responsibility: Do Conflicts Affect a Company's Corporate Social responsibility policy.» the Utrecht law revue volume $8, \mathrm{n}^{\circ} 03$ (november 2012): 53.

9. euromonitor, international. «Soft drinks in Algeria.» BOSTON, 2014. 10. GIZ et APAB. «Code de bonne conduite professionnelle.» avril 2014.

11. HARTMAN MONIKA. "corporate social responsibility in the food sector.» european review of agricultural economics 38 (3) (july 2011): 297-324.

12. Ipsos, Global Reputation Centre.reputation snapshot for the food and beverage sector. Ipsos global reputation centre, 2012, 02.

13. ISO. «guidance on social responsibility ISO 26000.» BERLIN , 2010. 14. MALONI.M.J, BROWN.M.E. «corporate social rsponsibility in the supply chain: application in the food industry.» journal of business ethics, 2006: 35-52.

15. NAHLI, NABIL. L'Eeconews. http://www.leconews.com/fr/actualites/nationale/commerce/10-desproducteurs-sont-dans-1-informel-11-02-2014-167618_292.php (accès le 12 13, 2015).

16. PME2. "Guide d'Utilisation des Additifs Alimentaires dans les Boissons PME II.» el mohammadia, ALGER, fevrier 2014.

17. PME2,APAB . lafiliaire des boison en algerieetude du mars-juillet 2012. alger : PME 2, 2012.

18. PRESCOTT,Dave. Alok, Singh. Aidan, Davy. «food for thought, corporate social responsability for food and beverage manufacturers.» the prince of WALES international business leaders forum, february 2002: 02.

19. www.fastmr.com. 2013. (accès le 112015,15 ). 